\title{
EMPIRICAL MODEL FOR OPTIMIZING SHEA BUTTER EXTRACTION IN AN UNBAFFLED VESSEL EQUIPPED WITH AN IMPELLER
}

\author{
Julius O modara ${ }^{1}$, Daniel Ayo², Moses Emetere ${ }^{3,4, *}$, \\ Ayodeji Ayoola ${ }^{1}$
}

https://doi.org/10.23939/chcht12.02.221

\begin{abstract}
The yield of Shea butter extracted in an unbaffled vessel equipped with an impeller was optimized by varying kneading time, kneading temperature and kneading speed using response surface method (RSM). Helical shaped impeller was mounted on a variable speed Tecmix TM 1100 kneader to knead the Shea paste. Minitab 16.1 software was used for the design and optimization of the process variables. The study indicated that the temperature and speed were highly significant on Shea butter oil yield with p-values of 0.001 and 0.002 , respectively. The residual plots of the yield show that the adopted model was efficient because the experimental and the predicted yields for the extraction are very close. It was concluded that the model to be adequate.
\end{abstract}

Keywords: Shea butter, optimization, yield, surface response method, Shea tree.

\section{Introduction}

Shea butter has been proven to be very good for the production of cosmetic and medicinal ointment [1]. It is used traditionally in West African countries for treating rheumatism, cough, wound, catarrh, and skin related treatments. It also serves as a good anti-inflammatory ointment [2-4]. Shea butter as an edible fat extract is highly nutritious. It is used for domestic cooking as well as a body cream [4-6]. Shea butter is a versatile vegetable plant fat [7] from dried kernels of Shea nuts, a derivative seed of Shea trees. Shea butter can be extracted by three methods: solvent extraction method, mechanical extraction (screw/hydraulic press), and traditional method. Though the yield from traditional method is lower

\footnotetext{
${ }^{1}$ Department of Chemical Engineering, Covenant University, P. M. B. 1023, Ota, Ogun State, Nigeria

${ }^{2}$ Department of Chemical Engineering, University of Lagos, Akoka, Lagos State Nigeria

${ }^{3}$ Department of Physics, Covenant University, P. M. B. 1023, Ota, Ogun State, Nigeria

${ }^{4}$ Department of Mechanical Engineering Science, University of

Johannesburg, Auckland Park Campus, Johannesburg, South Africa

*emetere@yahoo.com

(c) Omodara O., Ayo D., Emetere M., Ayoola A., 2018
}

compared to other methods, the demand for Shea butter extracted by traditional method in the cosmetic industry makes it the subject of interest. Though a number of researchers have proposed kneading vessels to produce Shea butter similar in quality to that produced by traditional method of kneading by hands or feet, the optimal conditions such as stirrer speed, kneading/ extraction temperature, and kneading time have not been agreed upon.

In terms of appearance, smell and quality, raw (crude or unrefined) Shea butter exhibits wide variations depending on the geographical location, origin as well as the method used for extraction [8]. C. Kelling [9] revealed that Shea butter has high UV-B absorbing triterpene esters, which include vitamin A (tocopherols), phytosterols cinnamic acid. The percentage of known unsaponifiable compounds in Shea butter includes alpha-spinosterol, campesterol phytosterols, beta-sitosterol, stigma sterol and triterpenes. On the average, the fatty acid compositions of Shea butter are (wt \%): palmitic acid (2.3-5.44), oleic acid (40.71-44.48), linoleic acid (6.0-6.41), stearic acid (39.74-45.0), and arachidic acid (<0.9) [10].

Generally, the fatty acid composition of the triglycerides of Shea butter is dominated by stearic, linoleic, and oleic acids. Also, the unsaponifiable Shea butter contains high percentage of cinnamic acid esters (triterpene alcohols) and sterols which carry the smallest fraction. Example of triterpene alcohol fund in Shea butter is butyrospermol, other important constituents are vitamin A (tocopherol), alpha- and beta-amyrin and lupuol [11]. Stearic, palmitic, linoleic, arachidic and oleic acids are five major fatty acids that characterize Shea butter [8]. Oleic and stearic acids account for about $85-90 \%$ of the fatty acids composition of Shea butter. The consistency of Shea butter is largely determined by the relative proportion of both the oleic and stearic acid compositions of the fatty acids. For instance, the softness and hardness of Shea butter are controlled by the percentage of oleic acid and stearic acid, respectively. C. Kelling [9] revealed that an antioxidant property of Shea butter is not unconnected to phenolic compounds present in it. It is 
good to note that the phenolic percentage composition and contents of Shea butter vary as the methods of Shea butter production do. In comparison, the phenolics of Shea butter extracted by traditional methods are usually more than those extracted by hexane [8]. Hence, the optimization of the traditional method was the main objective of this paper.

There are two major methods in optimization, namely conventional method and statistical method like factorial method, RSM method, and the like ones [12-13]. Response surface methodology (RSM) belongs to a statistical method of process optimization which has been found to be more popular and effective than the conventional method. RSM requires minimum experimental runs to determine the effect of the process input variables and their interactions as well as to identify the optimum input conditions that will generate the optimum yield [14]. RSM allows the use of derivative based algorithm that can generate a smooth function that minimizes an error and improve a convergence of the optimization process [15]. Hence, the objective of this research is to use the known mathematical model to optimize experimental extraction of Shea butter.

\section{Experimental}

\subsection{Statistical Technique}

In the optimization of the extraction of Shea butter from Shea nut a statistical technique was adopted. The vital parameters were represented using alphabets, for instance, the amount of kneading time coded as $\left(x_{1}\right)$, the level of kneading/extraction temperature $\left(x_{2}\right)$, the magnitude of the kneading speed $\left(x_{3}\right)$ and optimized Shea butter yield $(y)$. Here, the input variables (independent variables) are: kneading time $\left(x_{1}\right)$, kneading/extraction temperature $\left(x_{2}\right)$ and kneading speed $\left(x_{3}\right)$ while the output variable which is also known as dependent variable or response (yield) is $(y)$.

Hence,

$$
y=f\left(x_{1}, x_{2}, x_{3}\right)+\varepsilon
$$

$f\left(x_{1}, x_{2}, x_{3}\right)$ represents the surface termed "response surface"; $\varepsilon$ represents the error (noise) recorded in the yield $(y)$. The term $\varepsilon$ represents the error due to measurements. Statistically, the error is assumed to follow normal distribution with zero mean error and variance $s^{2}$.

Graphical representation of the response technique using 3-D surface or using contour plots will help to visualize the shape and geometry of the response surface.

Contours are curves of the constant response that indicate a particular height of the response surface drawn in the $x-y$ plane while all other variables are kept constant.
A first order model (approximation function) is suitable for a response that can be defined by a linear function of independent variables. Mathematical expression of the first order model with two independent variables can be written as:

$$
y=a_{0}+a_{1} x_{1}+a_{2} x_{2}+\varepsilon
$$

A higher degree polynomial was used for the response surface technique. For the second order model with two independent variables, the equation can be written as:

$$
y=a_{0}+a_{1} x_{1}+a_{2} x_{2}+a_{11} x_{11}^{2}+a_{22} x_{22}^{2}+a_{12} x_{1} x_{2}+\varepsilon
$$

According to Parampalli et al. [16], the design of an experiment is an important aspect of response surface methodology (RSM). The accuracy of the approximation and the cost implication of constructing the response surface are largely dependent on the choice of the design of experimentations. Parampalli et al. [16] have given an extensive description of the design of experiments theory for response surface methodology and multidisciplinary design optimization.

Minitab 16.1 is one of the popular and efficient software used for the analysis of the second order model. Analysis of variance for fitting the data, contour plots, 3D surface plot and response optimizer are the tools used for response characterization.

\subsection{M aterials and Methods}

The material used for the extraction includes: crusher, milling machine, kneading equipment (variable speed Tecmix TM 1100 kneader), stopwatch, digital weighing balance, thermometer, deep freezer, thermostatic control water bath, sieving cloth, crystal tachometer, electric stove.

The Shea nut was obtained from an open market in Nigeria. The black and bad nuts were sorted out and separated from the good nut. The nuts were soaked for about $30 \mathrm{~min}$ in hot water and washed repeatedly with the aid of warm tap water so as to avoid oxidation of oil emitted from a bad nut as well as to remove surface mould that might have formed during harvesting. The kernels were dried under the sun for about eight hours under weather temperature of $297 \mathrm{~K}$. Drying does not only dehydrate the moisture nuts but also exposes the bad nuts. The bad nuts are separated from the lot. The selected nuts were further reduced into smaller grits by a nut crusher making them ideal for milling. The algorithm for the extraction process is shown in Figs. 1 and 2. The crushed seeds (grit) were sun dried for about two hours (at about $297 \mathrm{~K}$ average daily temperature) to reduce the moisture content. This was done to enhance quick milling and save energy at the milling stage. The next stage involves the use of milling machine to grind the grit into a fine paste. The Shea nuts (if roasted) should ideally be allowed to 
cool down under ambient condition for at least $20 \mathrm{~min}$ prior milling.

The paste from the mill was then mixed with water and kneaded at a regulated speed sufficient to cause the fat to break away from the paste. As soon as kneading attains a stage where the fat was observed to break away from the paste, the excess volume of water was added and gently stirred with hand to enhance further break away of fat from Shea slurry to form emulsion. The emulsion is less dense than water so they rise to the surface by floatation and the cake settles at the bottom of the container. The fat was gathered (scooped) from the surface with a flat metal spoon. The crude butter/emulsion was boiled for about $45 \mathrm{~min}$. As a result of boiling, three distinctive fractions were formed: the froth that floats on the liquid oil (this is continuously skimmed off); the light yellow oil that floats on dark brown liquid; and the dark brown liquid at the bottom. The oil was filtered using a sieving cloth and then left in an open airy place to cool and to become semisolid. This is then stored in an appropriate container.

The kneading speed (in revolution per minute) was determined using photo/contact tachometer. This was done to know the actual rotational speed of the kneading impeller, the different rotational speeds of the kneader powered by variable speed electric motor (1100 watt capacity) were measured using a photo/contact tachometer. The speed was determined by operating the regulator of the variable speed electric motor while the tachometer sensor contacts the crystal lining attached to the rotating impeller and the measured value is shown on the liquid crystal display of tachometer (see Table 1).

\section{Results and Discussion}

RSM of 2-Level, 3-Factor, central composite design $(\mathrm{CCD})$ was used for the design of the experiment. The parameters obtained in the experiment are shown in Tables 1-5. Kneading time, kneading/extraction temperature, and kneading speed were variables and percentage oil yield was the response. The software used in this work is Minitab 16.1.

The percentage oil yield (response), predicted oil yield, as well as the residual value for each run (as contained in the $\mathrm{CCD}$ experimental design) is summarized in Table 4. The residual plot of oil yield is shown in Fig. 3 . The plot proves a high reliability of the model as the experimental yields and the predicted yields for the extraction are very close. This result is supported by other researchers $[17,18]$. A second-order polynomial model for the response is described by Eq. (4). Table 5 shows the linear, quadratic and the interaction terms for the model. The prediction was in terms of coefficient, $\mathrm{T}$-values and $\mathrm{P}$-values. The significance of each coefficient and their interactions were determined by using $t$-test $(\mathrm{T})$ and probability $(\mathrm{P})$. P-value less than 0.05 were considered significant. Hence, linear terms $\mathrm{B}$ and $\mathrm{C}$ are highly significant (with p-values of 0.001 and 0.002 , respectively) while A is less significant. Quadratic term $\mathrm{B}^{2}$ and $\mathrm{C}^{2}$ are significant while $\mathrm{A}^{2}$ is not significant. The interaction term $\mathrm{AC}$ is significant while $\mathrm{AB}$ and $\mathrm{BC}$ are not significant as the result of this, only significant ones have the greater effect on Shea butter oil yield.

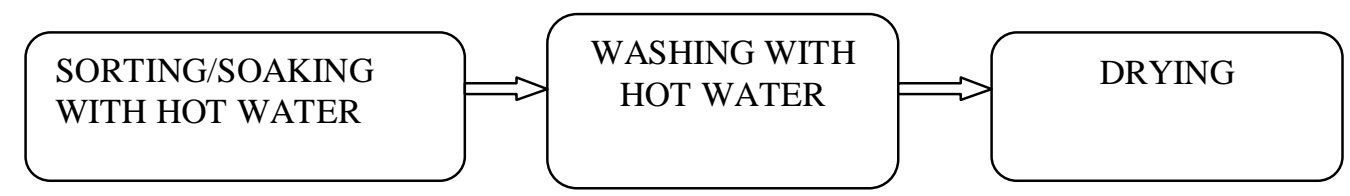

Fig. 1. Block flow diagram of seed preparation

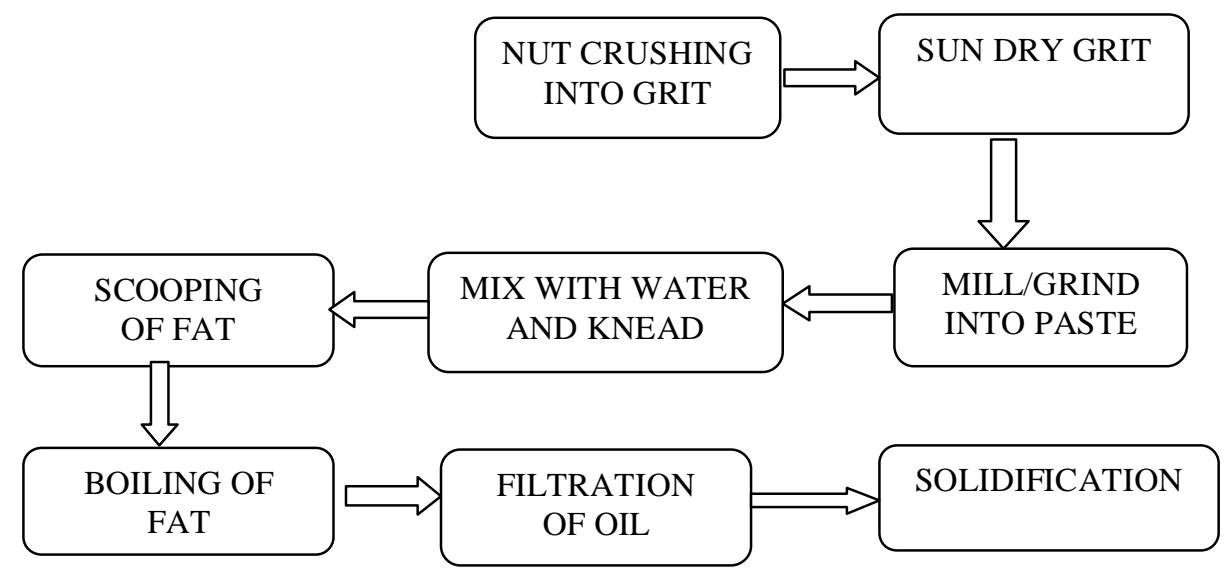

Fig. 2. Schematic diagram showing a mechanical method of extracting Shea butter 
Determination of the kneader speed in RPM using a crystal tachometer

\begin{tabular}{|c|c|}
\hline Selector speed & Speed, rpm \\
\hline 1 & 250 \\
\hline 2 & 400 \\
\hline 3 & 600 \\
\hline 4 & 800 \\
\hline 5 & 900 \\
\hline 6 & 1050 \\
\hline
\end{tabular}

Table 2

Experimental ranges of coded independent variables used in the CCD

\begin{tabular}{|l|c|c|c|c|}
\hline \multirow{2}{*}{ Factors } & \multirow{2}{*}{ codes } & -1 & 0 & 1 \\
\cline { 3 - 5 } & & 2 & 4.5 & 7 \\
\hline Time of kneading, min & $\mathrm{A}$ & 288 & 295.5 & 303 \\
\hline Temperature, $\mathrm{K}$ & $\mathrm{B}$ & 400 & 600 & 800 \\
\hline Kneading speed, rpm & $\mathrm{C}$ & \multicolumn{3}{|c}{} \\
\hline
\end{tabular}

Table 3

CCD experimental design generated from Minitab 16.1 software for coded and uncoded units

\begin{tabular}{|c|c|c|c|c|c|c|}
\hline Run order & A & B & $\mathrm{C}$ & A & B & $\mathrm{C}$ \\
\hline 1 & -1.68179 & 0 & 0 & 0.295518 & 22.5 & 600 \\
\hline 2 & 0 & 0 & -1.68179 & 4.5 & 22.5 & 263.6414 \\
\hline 3 & -1 & 1 & -1 & 2 & 30 & 400 \\
\hline 4 & 0 & 0 & 0 & 4.5 & 22.5 & 600 \\
\hline 5 & -1 & -1 & -1 & 2 & 15 & 400 \\
\hline 6 & 1 & 1 & 1 & 7 & 30 & 800 \\
\hline 7 & 0 & 0 & 1.68179 & 4.5 & 22.5 & 936.3586 \\
\hline 8 & 1 & -1 & -1 & 7 & 15 & 400 \\
\hline 9 & 0 & 0 & 0 & 4.5 & 22.5 & 600 \\
\hline 10 & 0 & -1.68179 & 0 & 4.5 & 9.886554 & 600 \\
\hline 11 & -1 & 1 & 1 & 2 & 30 & 800 \\
\hline 12 & -1 & -1 & 1 & 2 & 15 & 800 \\
\hline 13 & -1 & -1 & 1 & 7 & 15 & 800 \\
\hline 14 & 0 & 0 & 0 & 4.5 & 22.5 & 600 \\
\hline 15 & 0 & 1.68179 & 0 & 4.5 & 35.11345 & 600 \\
\hline 16 & 0 & 0 & 0 & 4.5 & 22.5 & 600 \\
\hline 17 & 0 & 0 & 0 & 4.5 & 22.5 & 600 \\
\hline 18 & 0 & 0 & 0 & 4.5 & 22.5 & 600 \\
\hline 19 & 1.68179 & 0 & 0 & 8.704482 & 22.5 & 600 \\
\hline 20 & 1 & 1 & -1 & 7 & 30 & 400 \\
\hline
\end{tabular}

The regression equation for the model is shown in Eq. (4):

$Y=9.12+0.673 \mathrm{~A}+0.803 \mathrm{~B}-0.0273 \mathrm{C}-0.0384 \mathrm{~A}^{2}-$

$-0.0143 \mathrm{~B}^{2}+0.000029 \mathrm{C}^{2}-0.0132 \mathrm{AB}+0.00120 \mathrm{AC}-$ $-0.00082 \mathrm{BC}$

where $Y$ is the oil yield in percentage. $Y$ was calculated using the second order model. A, B and C are coded values of variables for time, temperature and speed, respectively. The results of the second order model described by Eq. (4) are given in Table 3 in the form of analysis of variance.Table 6 reveals that Fisher's F-test of
39.0 and probability value $(\mathrm{P})$ of 0.00 are attributed to the regression model. The indication is that the regression model is highly significant. The observed and predicted oil yield indicates a good result between the polynomial regression model and experimental data. The $\mathrm{R}$-square $\left(\mathrm{R}^{2}\right)$ is 0.97 , this confirms the reliability of the model. It also implies that combination of values of 3 factors different from the template of the CCD experimental design but within the range of 2 levels, can be used and the regression coefficients will still be unaffected (constant). 97\% value of $\mathrm{R}^{2}$ suggests that the model may 
not be able to account for only $3 \%$ of the total variation. The adjusted determination coefficient $\left(\mathrm{AdjR}^{2}\right)$ of $94.74 \%$ shows that the model is highly efficient. It also implies that combination of values of 3 factors different from the template of the CCD experimental design within or outside the range of 2 levels, can be used and the regression coefficients will still be unaffected (constant). The coefficient of regression is considered significant if the corresponding value of $\mathrm{F}$ is high and the $\mathrm{P}$ value is less than 0.05. Hence, Table 6 shows coefficients that are significant and those that are not based on their corresponding $\mathrm{F}$ and $\mathrm{P}$ values.
Fig. 4 shows 3D response surface plot and 2D contour plot as a function of two factors while keeping the third factor constant at its central level. Fig. 4a depicts the response surface and contour plot of $\mathrm{B}, \mathrm{A}$ at a constant factor C, at level $600 \mathrm{rpm}$ (speed). Oil yield was observed from the plot to increase with temperature up to optimum point. Fig. $4 \mathrm{~b}$ shows the effect of factor A, B at a constant factor $\mathrm{C}$, at level $600 \mathrm{rpm}$. The oil yield increases with increasing A (kneading time) up to the optimum point as well as B (temperature) the effect of B is more prevalent than A because at high $B$ the system might have reached equilibrium.

Table 4

CCD experimental results, predicted and residual values

\begin{tabular}{|c|c|c|c|c|c|c|}
\hline Run order & A & B & C & Y(Obs $)$ & Y(Pred.) & Residuals \\
\hline 1 & 0.295518 & 22.5 & 600 & 12.78 & 13.24031 & -0.46031 \\
\hline 2 & 4.5 & 22.5 & 263.6414 & 15.78 & 16.62733 & -0.84733 \\
\hline 3 & 2 & 30 & 400 & 15.3 & 14.46345 & 0.836547 \\
\hline 4 & 4.5 & 22.5 & 600 & 16.5 & 17.06027 & -0.56027 \\
\hline 5 & 2 & 15 & 400 & 13.07 & 12.93824 & 0.131763 \\
\hline 6 & 7 & 30 & 800 & 22.43 & 21.86789 & 0.562105 \\
\hline 7 & 4.5 & 22.5 & 936.3586 & 23.91 & 24.04394 & -0.13394 \\
\hline 8 & 7 & 15 & 400 & 16.7 & 15.97274 & 0.727265 \\
\hline 9 & 4.5 & 22.5 & 600 & 16.8 & 17.06027 & -0.26027 \\
\hline 10 & 4.5 & 9.886554 & 600 & 13.8 & 14.13035 & -0.33035 \\
\hline 11 & 2 & 30 & 800 & 17.4 & 17.4334 & -0.0334 \\
\hline 12 & 2 & 15 & 800 & 16.8 & 16.39818 & 0.40182 \\
\hline 13 & 7 & 15 & 800 & 21.68 & 21.82268 & -0.14268 \\
\hline 14 & 4.5 & 22.5 & 600 & 17 & 17.06027 & -0.06027 \\
\hline 15 & 4.5 & 35.11345 & 600 & 14.8 & 15.45092 & -0.65092 \\
\hline 16 & 4.5 & 22.5 & 600 & 17.4 & 17.06027 & 0.339727 \\
\hline 17 & 4.5 & 22.5 & 600 & 17.38 & 17.06027 & 0.319727 \\
\hline 18 & 4.5 & 22.5 & 600 & 17.45 & 17.06027 & 0.389727 \\
\hline 19 & 8.704482 & 22.5 & 600 & 19 & 19.52097 & -0.52097 \\
\hline 20 & 7 & 30 & 400 & 16.8 & 16.50795 & 0.292048 \\
\hline
\end{tabular}

Table 5

Regression coefficients for percentage oil yield

\begin{tabular}{|c|c|c|c|c|c|}
\hline Term & Coefficients & SE Coeff. & $\mathrm{T}$ & $\mathrm{P}$ & $\mathrm{S} / \mathrm{N}$ \\
\hline Constant & 9.11567 & 3.644 & 2.50 & 0.031 & $\mathrm{~S}$ \\
\hline $\mathrm{A}$ & 0.67291 & 0.4729 & 1.42 & 0.185 & $\mathrm{~N}$ \\
\hline $\mathrm{B}$ & 0.80270 & 0.1778 & 4.51 & 0.001 & $\mathrm{~S}$ \\
\hline $\mathrm{C}$ & -0.02726 & 0.006669 & -4.09 & 0.002 & $\mathrm{~S}$ \\
\hline $\mathrm{A}^{2}$ & -0.03845 & 0.02776 & -1.39 & 0.196 & $\mathrm{~N}$ \\
\hline $\mathrm{B}^{2}$ & -0.01427 & 0.003084 & -4.63 & 0.001 & $\mathrm{~S}$ \\
\hline $\mathrm{C}^{2}$ & 0.00003 & 0.000004 & 6.68 & 0.000 & $\mathrm{~S}$ \\
\hline $\mathrm{AB}$ & -0.01320 & 0.01242 & -1.06 & 0.313 & $\mathrm{~N}$ \\
\hline $\mathrm{AC}$ & 0.00120 & 0.00047 & 2.57 & 0.028 & $\mathrm{~S}$ \\
\hline $\mathrm{BC}$ & -0.00008 & 0.00016 & -0.53 & 0.610 & $\mathrm{~N}$ \\
\hline
\end{tabular}

Notes: A - time of kneading; B - temperature; C - speed of kneading; S - significant; N - non-significant. $\mathrm{S}=0.658568, \mathrm{PRESS}=29.2307, \mathrm{R}^{2}=97.23 \%, \mathrm{R}^{2}(\mathrm{Pred})=81.33 \%$ and $\mathrm{R}^{2}(\mathrm{Adj})=94.74 \%$ 


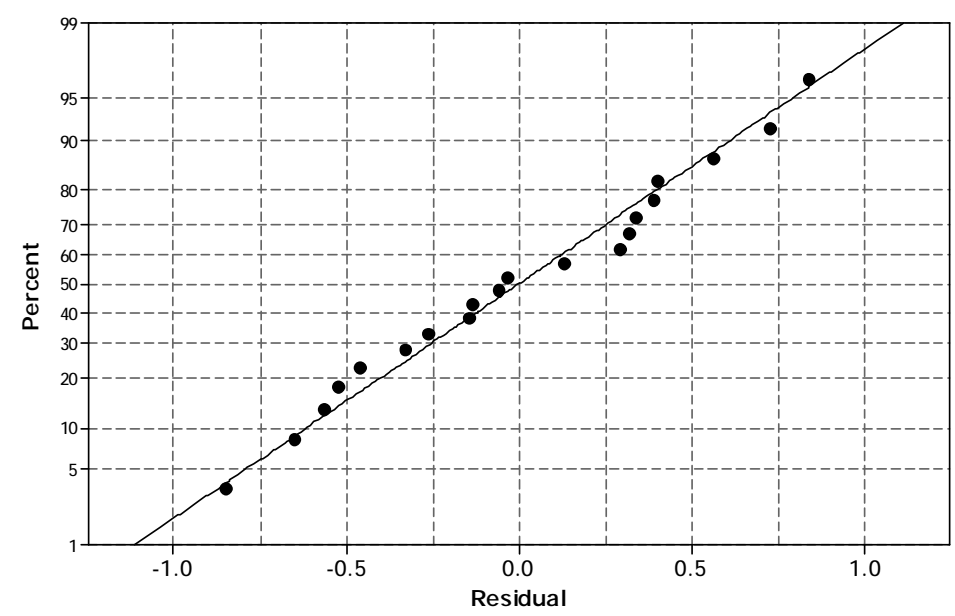

Fig. 3. Residual plots of Shea butter yield

Analysis of variances of model for the prediction of oil yield from Shea butter seed

\begin{tabular}{|l|c|c|c|c|c|c|}
\hline \multicolumn{1}{|c|}{ Source } & DF & SeqSS & AdjSS & AdjMS & F & P \\
\hline Regression & 9 & 152.250 & 152.250 & 16.9167 & 39.00 & 0.000 \\
\hline Linear & 3 & 116.120 & 25.003 & 8.3345 & 19.22 & 0.000 \\
\hline A & 1 & 47.616 & 0.878 & 0.8782 & 2.02 & 0.185 \\
\hline B & 1 & 2.105 & 8.837 & 8.8371 & 20.38 & 0,001 \\
\hline C & 1 & 66.398 & 7.245 & 7.2453 & 16.71 & 0.002 \\
\hline Square & 3 & 32.665 & 32.665 & 10.8882 & 25.10 & 0.000 \\
\hline $\mathrm{A}^{2}$ & 1 & 1.089 & 0.832 & 0.8321 & 1.92 & 0.196 \\
\hline $\mathrm{B}^{2}$ & 1 & 12.250 & 9.280 & 9.2795 & 21.40 & 0.001 \\
\hline $\mathrm{C}^{2}$ & 1 & 19.326 & 19.326 & 19.3256 & 44.56 & 0.000 \\
\hline Interaction & 3 & 3.466 & 3.466 & 1.1554 & 2.66 & 0.105 \\
\hline AB & 1 & 0.490 & 0.490 & 0.4900 & 1.13 & 0.313 \\
\hline AC & 1 & 2.856 & 2.856 & 2.8561 & 6.59 & 0.028 \\
\hline BC & 1 & 0120 & 0.120 & 0.1201 & 0.28 & 0.610 \\
\hline Residual error & 10 & 4.337 & 4.337 & 0.4337 & & \\
\hline Lack of fit & 5 & 3.587 & 3.587 & 0.7174 & 4.78 & 0.055 \\
\hline Pure error & 5 & 0.750 & 0.750 & 0.1500 & & \\
\hline Total & 19 & 156 & 588 & & & \\
\hline
\end{tabular}

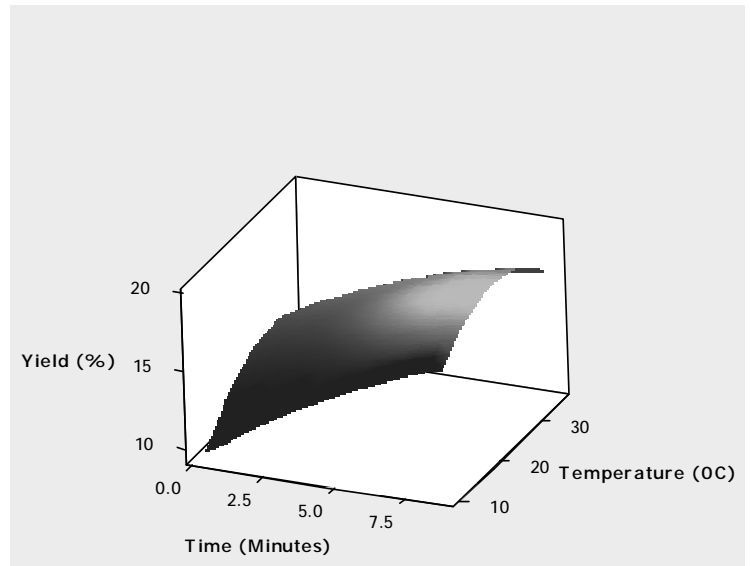

Fig. 4a. Surface plot of yield against temperature (B) and time (A)
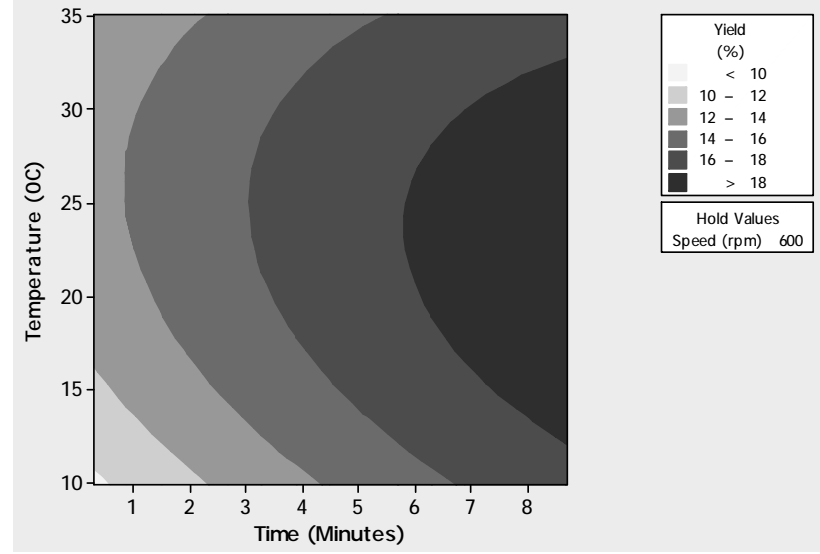

Fig. 4b. Contour plot of temperature (B) against time (A) 


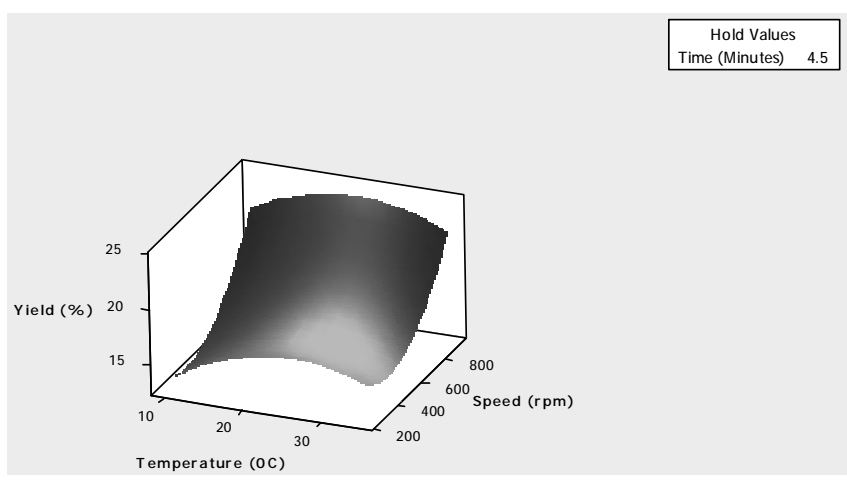

Fig. 5a. Surface plot of yield against speed (C) and temperature (B)

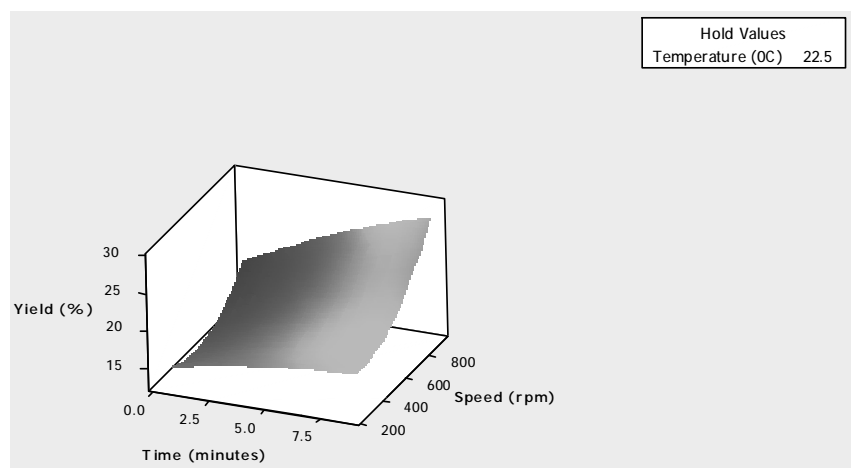

Fig. 6a. Surface plot of yield against speed (C) and time (A)

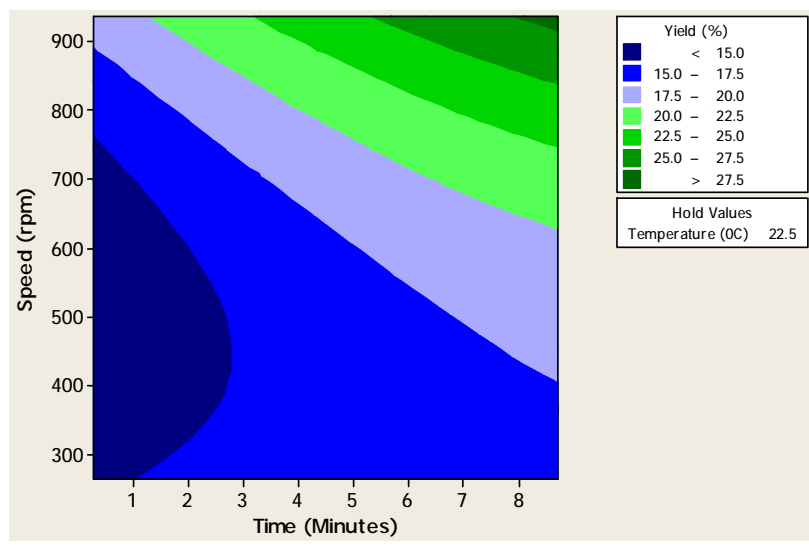

Fig. 5b. Contour plot of speed (rpm) against temperature $\left({ }^{\circ} \mathrm{C}\right)$

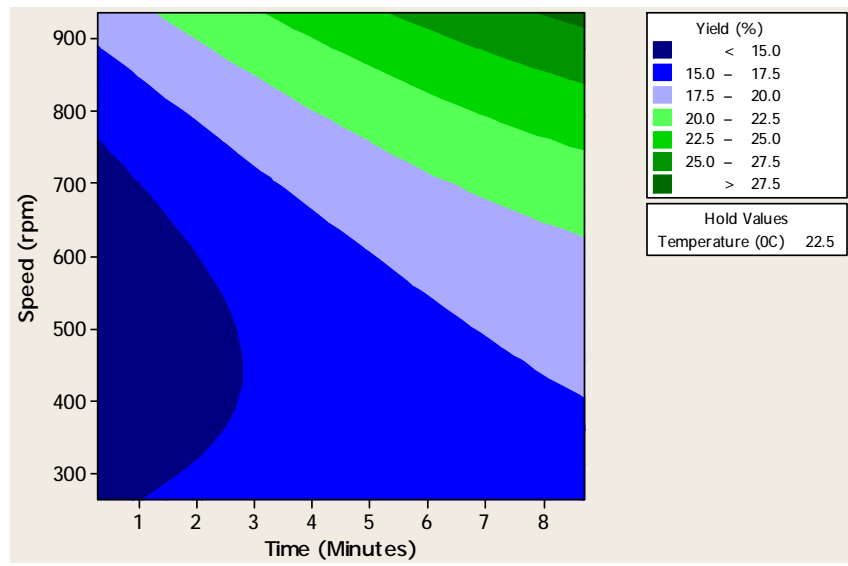

Fig. 6b. Contour plot of speed (C) against time (A)

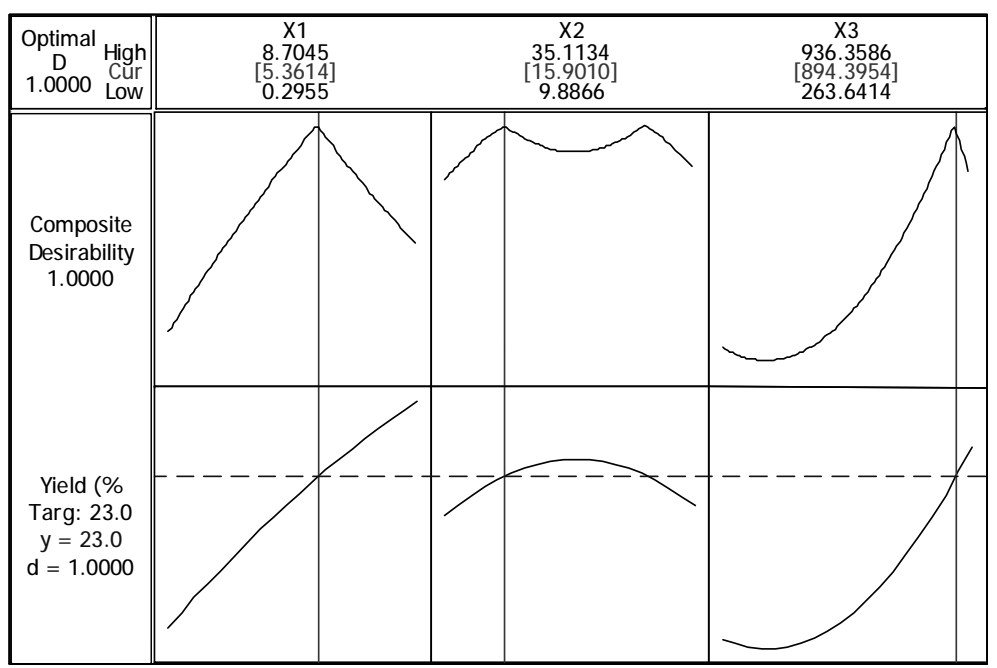

Fig. 7. Response optimizer for Shea butter yield 
The effect of extraction time (A) and speed (C) with constant extraction temperature (A) at level of 295.5 K can be seen in Fig. 4b. Linear effects of C are significant as shown in the regression table. Also quadratic effect of $\mathrm{B}^{2}$ and $\mathrm{C}^{2}$ were significant while quadratic effect of $\mathrm{A}^{2}$ was only marginally significant. Their interaction was significant for oil yield.

The optimum conditions for maximum oil yield according to the model optimizer are: time $5.4 \mathrm{~min}$, temperature $288.9 \mathrm{~K}$ and speed $894 \mathrm{rpm}$. Under these conditions the Shea butter oil yield is $23 \%$ (Fig. 7).

This model was validated by experimental run using the optimum conditions as established by the optimizer. The validated value of $24.04 \%$ is very close to the optimized value of $23 \%$ which proved the model to be adequate.

\section{Conclusions}

The yield of Shea butter depends on three main factors (kneading time, speed of kneading and kneading temperature). The temperature and speed of kneading were the major significant factors affecting the Shea butter yield. The optimized conditions as given by the response optimizer were $5.4 \mathrm{~min}, 288.9 \mathrm{~K}$ and $894.4 \mathrm{rpm}$ to give the yield of $23.0 \%$. Validated optimum conditions gave the yield of $24.0 \%$. This yield is very close to the optimized value which proved the model to be adequate.

Further works should include studying the effect of particle size, eccentricity of the impeller on Shea butter yield, thermodynamics and kinetics of the Shea butter extraction process is recommended.

\section{Acknowledgements}

The authors acknowledge the partial sponsorship of Covenant University.

\section{References}

[1] Goreja W.: Shea Butter: The Nourishing Properties of Africa's Best-Kept Natural Beauty. Amazing Herbs Press. New York 2004. [2] Tella A.: Br. J. Clin. Pharmac., 1979, 7, 495.

[3] Badifu G.: J. Food Comp. Anal., 1989, 2, 238.

[4] Olaniyan A., Oje K.: J. Food Sci. Technol., 2007, 44, 404

[5] Kar A., Mital H.: Plant Food Hum. Nutr., 1981, 31, 67.

https://doi.org/10.1007/BF01093889
[6] Chalfin B.: Shea Butter Republic: State Power, Global Markets, and the Making of an Indigenous Commodity. Routledge, New York 2004.

[7] Hee N., Hector J., Simon J.: J. Medicin. Act. Plants, 2012, 1, 69. [8] Maranz S., Wiesman J., Bisgaard B.: Agroforestry Syst., 2004, 60, 71 .

[9] Kelling C.: The Numerous Topical Benefits of Unrefined Shea Butter. Library Avenue, New Delhi 2008.

[10] Bouvet J.: J. Agricult. Food Chem., 2010, 58, 7811.

[11] Okoye N., Ajaghaku D., Okeke H. et al.: Pharm. Biol., 2014,

52, 1478. https://doi.org/10.3109/13880209.2014.898078

[12] Carley K., Kamera N., Reminga J.: Response Surface methodology, CASOS Technical Report, Carnegie Mellon University, Qatar 2004

[13] Bas D., Boyaci I.: J. Food Eng., 2007, 78, 836.

https://doi.org/10.1016/j.jfoodeng.2005.11.024

[14] Sharif K., Rahman M., Azmir J. et al.: J. Food Eng., 2014, 124, 105. https://doi.org/10.1016/j.jfoodeng.2013.10.003

[15] Fabian F.: Application of Response Surface Methodology and Central Composite Design for 5P12-RANTES Expression in the Pichia pastoris System. http://digitalcommons.unl.edu/chemengtheses/16 [16] Parampalli A., Eskridge K., Smith L. et al.: Cytotechnology, 2007, 54, 57. https://doi.org/10.1007/s10616-007-9074-3

[17] Uzun Y., Şahan T.: Arch. Environ. Protect., 2017, 43, 37. https://doi.org/10.1515/aep-2017-0015

[18] Xu W., Ge X.-D., Cheng D.-L. et al.: Chem. Eng. Technol., 2017, 40, 571. https://doi.org/10.1002/ceat.201600044

Received: May 17, 2017 / Revised: June 26, 2017 / Accepted: October 26, 2017

\section{ЕМПІРИЧНА МОДЕЛЬ ДЛЯ ОПТИМІЗАЦІЇ ЕКСТРАКЦІї ОЛІї ДЕРЕВА ШІ В РЕАКТОРІ З ГЛАДКИМИ СТІНКАМИ, ОБЛАДНАНОМУ ІМПЕЛЕРОМ}

Анотація. 3 використанням методу Бокса-Вілсона (МБВ) проведено оптимізацію виходу олії дерева ші, екстрагованого в реакторі з гладкими стінками, обладнаному імпелером, внаслідок зміни часу, температури та швидкості перемішування. Для досліджень застосовували гвинтовий імпелер, встановлений на швидкісному змішувачі Тестіх ТМ 1100. Для розроблення та оптимізації змінних процесу використана програма Minitab 16.1. Встановлено, що температура та швидкість мають значний вплив на вихід з р-значеннями $0,001 i$ 0,002, відповідно. Значення виходу олії відповідно до графіку залишків показують, щзо прийнята модель є ефективною, оскільки експериментальні та прогнозовані значення виходу дуже близькі. Доведено адекватність моделі.

Ключові слова: олія дерева ші, оптимізація, вихід, метод Бокса-Вілсона, дерево ші. 